\title{
QUALITY OF BUREAUCRACY AND OPEN-ECONOMY MACRO POLICIES
}

\author{
Chong-En Bai \\ Shang-Jin Wei \\ Working Paper 7766 \\ http://www.nber.org/papers/w7766

\section{NATIONAL BUREAU OF ECONOMIC RESEARCH \\ 1050 Massachusetts Avenue \\ Cambridge, MA 02138 \\ June 2000}

We thank Yi Wu for superb research assistance, Leonado Bertolini, Steven Levitt, Natalia Tamirisa, Gian Maria Milesi-Ferretti, and seminar participants at the World Bank, Florida International University, and the Federal Reserve Bank of New York for helpful comments, Bill Easterly, Gian Maria Milesi-Ferretti, and Natalia T. Tamirisa for some of the data. The views expressed herein are those of the authors and not necessarily those of the National Bureau of Economic Research, the World Bank, or any other organization that we are associated with.

(C) 2000 by Chong-En Bai and Shang-Jin Wei. All rights reserved. Short sections of text, not to exceed two paragraphs, may be quoted without explicit permission provided that full credit, including $\subseteq$ notice, is given to the source. 
Quality of Bureaucracy and Open-Economy Macro Policies

Chong-En Bai and Shang-Jin Wei

NBER Working Paper No. 7766

June 2000

JEL No. F38, F4

\begin{abstract}
$\underline{\text { ABSTRACT }}$
Bureaucratic quality in terms of the level of corruption varies widely across countries, and is in general slow to evolve relative to the speed with which many economic polices can be implemented such as the imposition of capital controls. In this paper, we study the possibility that quality of bureaucracy may be an important structural determinant of open-economy macro-policies, in particular, the imposition/removal of capital controls, and financial repression. We first derive a model that delivers such a result. Bureaucratic corruption translates into reduced ability by the government to collect tax revenue. Even if capital control/financial repression is otherwise inefficient, as long as the government needs the revenue for public goods provision, it would have to rely more on capital control/financial repression. For all countries for which we can obtain relevant data, we find that more corrupt countries are indeed more likely to impose capital controls, a pattern consistent with the model's prediction. The result of this paper suggests that a premature removal of capital controls mandated by outside institutions could reduce rather than enhance economic efficiency.
\end{abstract}

Chong-En Bai

School of Economics and Finance

906 K.K Leung Building

The University of Hong Kong

Pokfulam Road, Hong Kong

baic@hku.hk
Shang-Jin Wei

Kennedy School of Government

Harvard University

79 JFK Street

Cambridge, MA 02138

and NBER

shang-jin_wei@harvard.edu 


\section{Introduction}

Quality of bureaucracy varies widely across countries. In this paper, we examine its implications for open-economy macro policies. Specifically, we focus our discussion on the imposition of capital controls and financial repression as an example.

Capital controls and financial repression in developing countries were once considered a severe hindrance to economic development (McKinnon, 1973; and Shaw, 1973). Recently, in the aftermath of the 1997-98 Asian economic crisis, there is an interesting twist in the intellectual wisdom. Most economists now say that capital account liberalization without a proper domestic financial supervisory and regulatory structure in place is a recipe for financial disasters. Several prominent economists go one more step, arguing that the benefits of capital account liberalization are probably negligible (e.g., Rodrik, 1999), or that restrictions on capital movement can serve useful policy functions if one believes that international portfolio flows and short term credits are excessively volatile (Wyplosz, 1986; Rodrik, 1999; Rodrik and Velasco, 1999).

We choose to look at capital controls/financial repression from a different angle, namely, bureaucratic quality as a potential determinant. An important but sometime less appreciated fact is that quality of bureaucracy evolves slowly relative to the speed with which a government can implement many economic policies, such as to impose or remove capital controls. Widespread bureaucratic corruption in a country results in a loss in the ability by the government to collect fiscal revenues from the formal tax channel. Or more precisely, the marginal cost of collecting tax revenues rises with the level of corruption. As a consequence, to finance the provision of public goods, it would have to rely increasingly more on the otherwise inefficient capital control /financial repression. In this case, a premature removal of capital controls (such as what may be mandated by the Intemational Monetary Fund) could reduce rather than enhance economic efficiency. This is a separate point from the possibility that a premature removal of capital controls may increase the likelihood of a financial crisis.

There are two relevant strands of the literature. First, a number of papers have examined the consequences or determinants of bureaucratic corruption, including Rose-Ackerman (1978), Shleifer and Vishny (1993), Mauro (1995), Ades and Di Tella (1997 and 1999), and Wei 
(1997) $)^{1}$. Second, there are also a number of papers that have examined consequences or determinants of capital controls, including Alesina and Tabellini (1989), Epstein and Schor (1992), Dellas and Stockman (1993), Dooley and Isard (1980), Lane and Rojas-Suarez (1992), Mathieson and Rojas-Suarez(1993), Alesina, Grilli and Milesi-Ferretti (1994), Aizenman and Guidotti (1994), Bartolini and Drazeń (1997), and Grilli and Miles-Ferretti (1995).

As far as we know, none of the previous papers has directly looked at the connection between corruption and capital controls. Of course, those papers that emphasize the public finance motivation for capital controls are direct predecessors to this paper. Our contribution. is to argue (and to provide the first model and first piece of evidence) that bureaucratic corruption may be the underlying reason for the difficulty in tax collection and in turn for the greater reliance on capital controls.

It is possible that the existence of capital controls breeds corruption as firms/individuals find it necessary to pay bribes in order to circumvent the control. Indeed, we need to take into account this possibility when we turn to the empirical examination. The central focus of this paper is on the reverse question: how the imposition and severity of capital controls are affected by the extent of corruption in the country. In other words, we take the extent of bureaucratic corruption as an exogenous "state of nature," in the sense that it is part of the public institutional infrastructure that is slow to evolve. More precisely, a government or top political leader is assumed to be able to impose/remove capital control or change its severity much more swiftly than she can with the extent of bureaucratic corruption in the country ${ }^{2}$.

While we use the term "bureaucratic corruption" in the paper, we actually have in mind various dimensions of the quality of bureaucracy, including government efficiency and burden of regulation, and not just bribe-taking by officials. Unfortunately, there does not exist separate data that allows us to measure separately the different dimensions of bureaucratic quality. What we can feasibly gather are measures of bureaucratic corruption based on the perceptions of experts, firm managers or citizens. Our suspicion is that the different dimensions of bureaucratic quality are highly correlated. Nonetheless, it is useful to keep this broad perspective in mind in interpreting our results.

\footnotetext{
See Pardhan (1997) and Wei (2000) for a more complete review of the literature.

${ }^{2}$ A possible extension of the model is to allow comuption and capital controls (or policy distortions in general) to influence each other, possibly leading to multiple equilibria.
} 
Our paper is organized in the following way. Section 2 presents a model that formalizes our story. Section 3 describes the data that are used in the empirical analysis. Section 4 reports the empirical evidence on our hypothesis. Finally, section 5 concludes.

\section{A Theoretical Model}

In this section, we present a theoretical model in which capital control is endogenously determined by the government in a way that is related to the level of corruption in the country. Our model assumes a welfare maximizing government (top leader) who collects revenue to provide public goods, but our central story would go through if the top leader simply collects revenue for her private consumption.

\subsection{Setup of the Model}

We consider a model with a representative investor in the private sector, a bureaucrat, and a government. The representative private investor's utility increases with the amount of the public good provided by the government, denoted by $X$, as well as his private consumption, denoted by $Y$, whose price is normalized to be one. Specifically, we assume that the expected utility function is

$$
\mathrm{U}_{\mathrm{p}}=\mathrm{E}\left\{-\mathrm{e}^{-\delta \mathrm{Y}-\gamma \mathrm{X}}\right\},
$$

where $\delta>0$ and $\gamma>0$.

The investor is endowed with a fixed wealth $Y_{0}$. His consumption depends on $\operatorname{tax} T$ and investment opportunities. We assume that he can invest his net wealth $Y_{0}-T$ in a portfolio of domestic and foreign assets. Denote the return to the domestic asset by $R_{d}$ and that to the foreign asset by $\mathrm{R}_{\mathrm{f}}$. The two returns can be different for reasons we will discuss later. Suppose the investor allocates $\alpha$ share of his net wealth to the foreign asset. Then his consumption will be

$$
Y=\left(Y_{0}-T\right)\left[\alpha R_{f}+(1-\alpha) R_{d}\right] \text {. }
$$

For simplicity, let us say that both the domestic and foreign assets are risk free. In the absence of capital controls, both are equal to the world interest rate, $R_{f}=R_{d}=r^{*}$. Of course, in this case, the representative domestic agent is indifferent between domestic and foreign assets, and the optimal $\alpha$ is undetermined. 
In this model, we recognize that capital control is an instrument of financial repression. It has two effects. First, because circumventing capital control is costly, it reduces the rate of return on investing aboard that is available to domestic investor, so that now $R_{\mathrm{f}}<\mathrm{r}^{*}$. Second, because circumventing capital control runs the risk of being caught and punished, the effective rate of return on the foreign asset faced by the domestic agent now becomes risky, and in equilibrium would on average be somewhat higher than the domestic (still risk-free) interest rate, $E\left\{R_{f}\right\}>R_{d}$. To be simple and concrete, we will assume (rather than derive) a specific functional form linking the extent of capital control, denoted by $\mathrm{k}$, and the equilibrium domestic and foreign rates of return.

$$
\begin{aligned}
& R_{d}=r^{*}-\rho k \\
& R_{f}=r^{*}-\rho k+\rho_{f} k+k v
\end{aligned}
$$

where $\rho$ is the effectiveness of capital control, $v$ is a random variable with a normal distribution $\mathrm{N}\left(0, \sigma^{2}\right)$ and represents the risk that capital control causes to investing in foreign assets, and $\rho_{\mathrm{f}}$ indicates that capital control is less effective in depressing the return to foreign assets than to domestic assets. Ideally, we should assume a distribution for the random variable, $v$, that is bounded from above. For simplicity, we make it an unbounded normal variable.

The amount of public good provided by the government, $X$, depends on its available resources, denoted by $Z$.

$$
X=f(Z) \text {, }
$$

where $f$ is an increasing and concave function.

The government raises tax $T$. Due to corruption, part of the tax revenue is stolen by the bureaucrat. Suppose the bureaucrat's stealing is

$$
\mathrm{S}=\mathrm{S}(\mathrm{T}, \theta)
$$

where $\theta$ is a parameter representing the weakness of governance, or the degree of corruption. We assume that $\mathrm{S}$ is increasing in $\mathrm{T}$ and $\theta$ respectively and is convex in $\mathrm{T}$. Furthermore, $\mathrm{S}_{\mathrm{T} \theta}>0$. In other words, as either the total amount of tax or corruption increases, stealing by bureaucrats also increases. Furthermore, as either total tax or corruption increases, marginal stealing per unit of tax collected also increases. In Appendix A, we offer a plausible justification for these assumptions. We label the fraction of formal taxes that disappears as "stealing" by the corruption-prone bureaucrats. Alternatively, we could also interpret it as "waste" of government resources by the inefficient and corrupt bureaucrats. 
The government's total usable fiscal resources, Z, consist of two components: an explicit tax revenue net of stealing (or waste), and an implicit tax revenue derived from financial repression. One possible example of implicit revenue is the saving by the government in its cost of borrowing from the domestic capital market when the domestic interest rate is artificially suppressed to below the world interest rate ${ }^{3}$. We assume that the implicit revenue from the financial depression depends on the reduction in domestic interest rate as a result of capital controls, $\rho k$, and the total amount of domestic savings, $\left(\mathrm{Y}_{0}-\mathrm{T}\right)$. Then,

$$
\mathrm{Z}=[\mathrm{T}-\mathrm{S}(\mathrm{T}, \theta)]+\left[\phi \rho \mathrm{k}\left(\mathrm{Y}_{0}-\mathrm{T}\right)\right]
$$

In Appendix $\mathrm{C}$, we employ an alternative assumption in which the implicit tax revenue is $\phi \rho k(1-\alpha)\left(Y_{0}-T\right)$. In other words, it depends only on the amount of domestic savings that is not invested aboard. We show that while this complicates the mathematical derivations, the basic qualitative conclusion of the model is still the same.

We consider a sequential game in which the government moves first, choosing explicit tax $\mathrm{T}$ and the degree of capital control $\mathrm{k}$ to maximize the social welfare, taking as given the weakness of the public institution (i.e. the extent of corruption), the bureaucrat's stealing function, and the private investor's reaction function. The representative private investor moves next, choosing an optimal allocation between capital flight and domestic investment, taking into account the tax and capital control. We solve the game with backward induction.

\subsection{The Private Investor's Decision}

Given his portfolio choice $\alpha$, the private investor's consumption is

$$
\mathrm{Y}=\left(\mathrm{Y}_{0}-\mathrm{T}\right)\left(\mathrm{r}^{*}-\rho \mathrm{k}+\alpha \rho_{\mathrm{f}} \mathrm{k}+\alpha \mathrm{kv}\right) \text {. }
$$

Then, his expected utility is

$$
-\mathrm{e}^{-\gamma \mathrm{X}} \mathrm{e}^{-\delta C E} \text {, }
$$

where

$$
\mathrm{CE}=\left(\mathrm{Y}_{0}-\mathrm{T}\right)\left(\mathrm{r}^{*}-\rho \mathrm{k}+\alpha \rho \mathrm{k}\right)-0.5 \delta \alpha^{2} \mathrm{k}^{2}\left(\mathrm{Y}_{0}-\mathrm{T}\right)^{2} \sigma^{2}
$$

is his certainty equivalent consumption level. Then, an expected utility maximizing investor should choose $\alpha$ to maximize CE. The first-order condition for $\alpha$ is

\footnotetext{
${ }^{3}$ One could also think of seigniorage revenue as another source of implicit revenue. Giovannini and de Melo (1993) made a conceptual distinction between financial repression and seigniorage, but also showed that the two are positively correlated across countries.
} 


$$
\left(\mathrm{Y}_{0}-\mathrm{T}\right) \rho_{\mathrm{f}} \mathrm{k}-\delta \alpha \mathrm{k}^{2}\left(\mathrm{Y}_{0}-\mathrm{T}\right)^{2} \sigma^{2}=0
$$

and the optimal choice of $\alpha$ is

$$
\alpha^{*}=\left[k \rho_{f}\right] /\left[\delta k^{2} \sigma^{2}\left(Y_{0}-T\right)\right]=\rho_{f} /\left[\delta k \sigma^{2}\left(Y_{0}-T\right)\right] .
$$

$\alpha^{*}$ is the proportion of after tax wealth invested in foreign assets, or the extent of capital flight. The above equation implies that capital flight decreases with the risk of the flight, $\mathrm{k}^{2} \sigma^{2}$ and with the rate of risk aversion, $\delta$, but increases with the premium of investing aboard, $k \rho_{\mathrm{f}}$

Given the optimal portfolio choice $\alpha^{*}$, the private investor's utility level is

$$
\mathrm{U}_{\mathrm{p}}^{*}=-\exp \left\{-\gamma \mathrm{f}\left[\mathrm{T}-\mathrm{S}(\mathrm{T}, \theta)+\phi \rho \mathrm{k}\left(\mathrm{Y}_{0}-\mathrm{T}\right)\right]-\delta\left(\mathrm{Y}_{0}-\mathrm{T}\right)\left(\mathrm{r}^{*}-\rho \mathrm{k}\right)-0.5 \rho_{\mathrm{f}}{ }^{2} / \sigma^{2}\right\}
$$

\subsection{The Government's Decision}

The government chooses $\mathrm{k}$ and $\mathrm{T}$ to maximize the above utility level of the representative private investor, or equivalently, the government maximizes

$$
\mathrm{U}_{\mathrm{g}}(\mathrm{k}, \mathrm{T})=\gamma \mathrm{f}\left[\mathrm{T}-\mathrm{S}(\mathrm{T}, \theta)+\phi \rho \mathrm{k}\left(\mathrm{Y}_{0}-\mathrm{T}\right)\right]+\delta\left(\mathrm{Y}_{0}-\mathrm{T}\right)\left(\mathrm{r}^{*}-\rho \mathrm{k}\right)+0.5 \rho_{\mathrm{f}}{ }^{2} / \sigma^{2}
$$

Lemma 1: Suppose $\phi r^{*}<1$ and $\theta$ is not too small. Then, the optimal $T$ is determined by

$$
S_{T}(T, \theta)=1-\phi r^{*}
$$

and the optimal $k$ is determined by

$$
T-S(T, \theta)+\phi \rho k\left(Y_{0}-T\right)=\left(f^{\prime}\right)^{-1}[\delta /(\gamma \phi)] .
$$

Proof: The government's objective function $U_{g}$ is not necessarily concave in $T$. Therefore, it is not clear whether or not the first order conditions of the optimization problem are sufficient. To circumvent this problem, we maximize the objective function in two steps.

First, for any given $T, U_{g}$ is a concave function of $k$ and the optimal $k$ satisfies the firstorder condition

$$
\gamma \mathrm{f}^{\prime}\left[\mathrm{T}-\mathrm{S}(\mathrm{T}, \theta)+\phi \rho \mathrm{k}\left(\mathrm{Y}_{0}-\mathrm{T}\right)\right] \phi \rho\left(\mathrm{Y}_{0}-\mathrm{T}\right)-\delta \rho\left(\mathrm{Y}_{0}-\mathrm{T}\right)=0,
$$

or

$$
\gamma \mathrm{f}\left[\mathrm{T}-\mathrm{S}(\mathrm{T}, \theta)+\phi \rho \mathrm{k}\left(\mathrm{Y}_{0}-\mathrm{T}\right)\right] \phi-\delta=0,
$$

which implies

$$
T-S(T, \theta)+\phi \rho k\left(Y_{0}-T\right)=\left(f^{-1}\right)^{-1}[\delta /(\gamma \phi)] \equiv Z^{*} .
$$


Then, the government's problem becomes to maximize $U_{g}$ subject to the above first-order condition for $\mathrm{k}$; that is,

$$
\begin{aligned}
& \operatorname{Max}_{\mathrm{T}} \mathrm{U}_{\mathrm{g}}(\mathrm{k}, \mathrm{T})=\gamma \mathrm{f}\left[\mathrm{T}-\mathrm{S}(\mathrm{T}, \theta)+\phi \rho \mathrm{k}\left(\mathrm{Y}_{0}-\mathrm{T}\right)\right]+\delta\left(\mathrm{Y}_{0}-\mathrm{T}\right)\left(\mathrm{r}^{*}-\rho \mathrm{k}\right)+0.5 \rho_{\mathrm{f}}{ }^{2} / \sigma^{2} \\
& \text { subject to: } \mathrm{T}-\mathrm{S}(\mathrm{T}, \theta)+\phi \rho \mathrm{k}\left(\mathrm{Y}_{0}-\mathrm{T}\right)=\mathrm{Z}^{*}
\end{aligned}
$$

From the constraint,

$$
\rho \mathrm{k}\left(\mathrm{Y}_{0}-\mathrm{T}\right)=\left[\mathrm{Z}^{*}-\mathrm{T}+\mathrm{S}(\mathrm{T}, \theta)\right] / \phi .
$$

Substitute the above equation into $U_{g}$. Then

$$
\begin{aligned}
\mathrm{U}_{\mathbf{g}}(\mathrm{T}) & =\gamma \mathrm{f}\left(\mathrm{Z}^{*}\right)+\delta \mathrm{r} *\left(\mathrm{Y}_{0}-\mathrm{T}\right)-\delta \rho \mathrm{k}\left(\mathrm{Y}_{0}-\mathrm{T}\right)+0.5 \rho_{\mathrm{f}}^{2} / \sigma^{2} \\
& =\gamma \mathrm{f}\left(\mathrm{Z}^{*}\right)+\delta \mathrm{r} *\left(\mathrm{Y}_{0}-\mathrm{T}\right)-\delta\left[\mathrm{Z}^{*}-\mathrm{T}+\mathrm{S}(\mathrm{T}, \theta)\right] / \phi+0.5 \rho_{\mathrm{f}}^{2} / \sigma^{2} .
\end{aligned}
$$

By the assumption that $S(T, \theta)$ is convex in $T$, the reduced form of $U_{g}$ is concave in $T$. Then the optimal $T$ is determined by the first-order condition that

$$
\mathrm{U}_{\mathrm{g}}{ }^{\prime}(\mathrm{T})=-\delta \mathrm{r}^{*}+\delta / \phi-\delta \mathrm{S}_{\mathrm{T}}(\mathrm{T}, \theta) / \phi=0,
$$

or

$$
\mathrm{S}_{\mathrm{T}}(\mathrm{T}, \theta)=1-\phi r^{*}
$$

Remark 1: If $\phi$ is so large that $1-\phi r^{*}<0$, or in other words, if financial repression is very effective at raising revenue for the government, the optimal $T=0$. To see this, note that $U_{g}{ }^{\prime}(T)<$ 0 for all $\mathrm{T}$ if $1-\phi r^{*}<0$.

Remark 2: Suppose $1-\phi r^{*}>0$. If corruption is negligible and hence stealing by the bureaucrat is negligible, then it is optimal not to have any capital control. Specifically, if $\theta$ is so small that $\mathrm{S}_{\mathrm{T}}(\mathrm{T}, \theta)<1-\phi \mathrm{r}^{*}$ for all $\mathrm{T}<\mathrm{Y}_{0}$, then $\mathrm{U}_{\mathrm{g}}(\mathrm{T})>0$ for all $\mathrm{T}<\mathrm{Y}_{0}$ and it is optimal to choose $\mathrm{T}$ as large as is necessary to fulfill the need for public good provision and to choose $\mathrm{k}=0$.

The lemma implies that both direct taxation and capital control are used for the government to obtain resources to finance public good provision. The intuitive reason for this mixture to be optimal is as follows. The stealing function $S(T, \theta)$ is convex in $T$. Therefore, the marginal cost of $T$ increases. On the other hand, the marginal cost of capital control - depressed return to investment - is a constant. Then, the marginal cost of $\mathrm{T}$ is higher than that of $\mathrm{k}$ when $\mathrm{T}$ is too high, and is lower when $T$ is too low. As a result, only part of the expenditure for public good provision should be financed by direct taxation $T$. 


\section{4. Comparative Statics}

Proposition 1: The optimal capital control $k$ increases with the level of bureaucratic corruption $\theta$, while the optimal tax collection $T$ decreases with the corruption level $\theta$.

The proofs for this proposition and the next are provided in Appendix B. The results in Proposition 1 are not difficult to understand intuitively. As corruption increases, more tax revenue will be stolen, then it is more desirable to finance the public good by capital control/financial repression rather than by direct taxation.

Proposition 2: (i) The optimal tax $T$ is independent of the degree of risk aversion $\rho$ but the optimal capital control $k$ decreases with $\rho$. (ii) The optimal tax $T$ decreases with $\phi$ but the relationship between the optimal $k$ and $\phi$ is ambiguous. (iii) The optimal $T$ is independent of $\gamma$ and $\delta$, but the optimal $k$ increases with $\gamma$ and decreases with $\delta$, where $\gamma$ is the importance of the public good in the representative private investor's utility while $\delta$ is that of private consumption.

(iv) The optimal $T$ and $k$ are both independent of $\rho_{f}$ and $\sigma^{2}$.

Intuitively, as $\rho$ increases, the returns to investment decrease, and the government resources from capital control increase, at the same proportion. This implies that the level of public good provision and T should not change. With the increase in the government's ability to extract resources from capital control, there is less need for the control in order to obtain the given level of resources for public good provision; that is the optimal $\mathrm{k}$ decreases. This is the reason for part (i) of Proposition 2.

The intuition for (ii) is as follows. As $\phi$ increases, the government can get more resources from capital control and therefore has less need for direct taxation, resulting in lower $\mathrm{T}$. The increase in $\phi$ has two effects on $\mathrm{k}$. The positive one (similar to the substitution effect) is that more resources should be extracted from capital control and the negative one (similar to the income effect) is that less control is needed in order to extract a given level of resources. It is not clear which one of these effects dominate. 
As the public good becomes more important to the investor's utility relative to private consumption, i.e., as $\gamma$ increases or $\delta$ decreases, the benefit of capital control - increasing the resources available for public provision - becomes larger and the cost of capital control decreasing the returns to private investment - becomes smaller. Therefore, k should increase. The effect of $\gamma$ and $\delta$ on $T$ is not so straightforward. When the public good becomes more important, it seems that more tax should be levied to increase public good provision. A larger $T$, however, reduces the opportunity for the government to obtain resources from capital control, thus reducing public good provision. The two effects of $T$ happen to cancel with each other in this model. As a result, the optimal $\mathrm{T}$ is independent of $\gamma$ and $\delta$. This is the reason for (iii).

To understand (iv), note that $\rho_{\mathrm{f}}$ and $\sigma^{2}$ enter into the government's objective function $\mathrm{U}_{\mathrm{g}}(\mathrm{k}, \mathrm{T})$ only through a term that is independent of $\mathrm{k}$ and $\mathrm{T}$. Therefore, the marginal effects of $\mathrm{k}$ and $T$ on $U_{g}(k, T)$ are independent of $\rho_{f}$ and $\sigma^{2}$. Consequently, the optimal $k$ and $T$ are both independent of $\rho_{\mathrm{f}}$ and $\sigma^{2}$.

\section{Data}

The detailed definition and source for the data as well as their manipulation are explained in Appendix D. Here, we provide a brief description on the most important variables in our empirical analysis.

\section{$\underline{3.1 \text { Capital Control }}$}

Our capital controls are derived from the annual issues of the IMF's. There are five categories of restrictions on foreign exchange transactions that the IMF has consistently coded throughout our sample, 1984-1997. They are (1) existence of multiple exchange rates, (2) payment arrears and bilateral payments arrangement, (3) controls on payments for invisible transactions and current transfers, (4) controls on proceeds from exports and/or invisible transactions, and finally, (5) controls on capital account transactions. For each category, the IMF source indicates whether the country has restriction or not.

We derive a discreet-valued measure of the severity of capital control by aggregating the five categories. Thus, the measure can take one of the six values from zero to five, with zero if 
the country has no controls in any of the five categories, and five if it has controls in all five categories. The exact definitions of the six categories provided in Appendix B.

\subsection{Bureaucratic Corruption}

We use four different measures of corruption: ICRG, GCR, WDR, and TI indexes. In addition, we use two variables as instrumental variables for corruption: legal corruption and democracy.

\section{(A) International Country Risk Guide (ICRG) Index.}

Produced every year since 1982 by Political Risk Services, a private international investment risk service. The ICRG corruption index is apparently based on the opinion of experts and supposed to capture the extent to which "high government officials are likely to demand special payments" and to which "illegal payments are generally expected throughout lower levels of government" in the form of "bribes connected with import and export licenses, exchange controls, tax assessments, police protection, or loans."

\section{(B) Global Competitiveness Report (GCR) Index}

Unlike the ICRG indices, the GCR Index is based on a 1996 survey of firm managers, rather than experts or consultants. Sponsored by the World Economic Forum (WEF), a Europebased consortium with a large membership of firms, and designed by the Harvard Institute for International Development (HIID), this survey asked the responding firms about various aspects of "competitiveness" in the host countries where they invest. 2381 firms in 58 countries answered the question on corruption which asked the respondent to rate the level of corruption on a one-to-seven scale according to the extent of "irregular, additional payments connected with import and export permits, business licenses, exchange controls, tax assessments, police protection or loan applications." The GCR corruption index for a particular country is the average of all respondents' ratings for that country.

(C) World Development Report (WDR) Index

Similar to the GCR Index, the WDR index is based on a 1996 survey of firms conducted by the World Bank for its 1997 World Development Report. Every respondent was asked a long 
list of questions, one of which was on perceived level of corruption. The question is essentially identical to the one in the GCR survey. The WDR survey covers over 70 or so countries (many of which are not in the WDR sample, and the reverse is also true). The WDR survey tend to cover more medium and small firms whereas the GCR survey had more large firms.

\section{(D) Transparency International (TI) Index}

Produced annually since 1995 by Transparency International, an international nongovernmental organization dedicated to fight corruption worldwide, the index is based on a weighted average of approximately ten surveys of varying coverage. It ranks countries on a oneto-ten scale.

As a survey of surveys, the TI index has its advantages and disadvantages. If the measurement errors in different surveys are independent and identically distributed (iid), the averaging process used to produce the TI index may reduce the measurement error. But iid assumption may not hold. Moreover, since different surveys cover different subsets of countries, the averaging process may introduce new measurement errors when cross-country rankings are produced. One should also note that, as the TI indexes in different years are derived from potentially different set of surveys, they should not be used to measure changes in corruption level over time for a particular country.

\section{E. First IV for Corruption: Democracy}

The measure of democracy is derived by adding up an index for civil liberties and another for political rights, both are composed by the Freedom House. Liberties index measures the extent to which people are able to express their opinion openly without fears of reprisals and are protected in doing so by an independent judiciary. Though this index reflects rights to organize and demonstrate as well as freedom of religion, education, travel and other personal rights; more weight was given to those liberties that are most directly related to the expression of political rights. This variable is an index and not in logs.

Political rights index measures rights to participate meaningfully in the political process on a scale of one to seven where lower numbers indicate greater political rights (see Gastil, 1989). A high ranking country must have a fully operating electoral procedure, usually including a significant opposition vote. It is likely to have had a recent change of government from one party 
to another, an absence of foreign domination, decentralized political power and a consensus that allows all segments of the population some power. The index was constructed on the basis of satisfaction of the above and other related criteria by the countries in question. This variable is an index and not in logs.

Both Index range from 1 to 7 . Smaller number means higher degree of freedom. Democracy is defined as (7-civ) $+(7-$ pol $)$.

\section{F. Second IV Variable for Bureaucratic Corruption: Corruption in the Judicial Svstem}

Corruption in a country's judicial system is based on the same GCR survey that produced the GCR bureaucratic corruption measure. Question 8.09 in the survey asked the respondents to rate the level of corruption in the judicial system based on the extent to which"[i]rregular payments to judges or other officials involved in the enforcement and execution of judgements are not common and do not influence the outcome of court proceedings" ( $1=$ strongly disagree, $7=$ strongly agree). We rescaled the index ( 7 - original score) so that a larger number means more corrupt judicial system.

Tables $1 \mathrm{a}$ and $\mathrm{lb}$ report summary statistics for the key variables and their pairwise correlations.

\section{Statistical Analysis}

Since our measure of capital controls can take seven discrete values from a minimum of zero to a maximum of five, we employ an ordered Probit specification:

\section{Capital Control in Country $\mathrm{j}=\mathrm{k}$}

if $\quad D_{k}<Y_{j}^{*} \leq D_{k+1}$

where $Y_{j}^{*}=\theta$ Corruption $_{j}+X_{j} \beta+e_{j}$

$\mathrm{k}=0,1,2, \ldots, 5 ; \mathrm{D}_{0}=-\infty$. and $\mathrm{D}_{6}=\infty ; \mathrm{D}_{1}, \ldots, \mathrm{D}_{5}$ are parameters to be estimated together with scalar $\theta$ and vector $\beta ; X$ is a vector of control variables other than corruption; and $e_{j}$ is an independently and identically distributed normal variate with a zero mean. 
Table 2 presents simple regressions of the measure of capital control severity on corruption and a dummy indicating membership in OECD. OECD membership in recent years often requires capital account liberalization (which was the case when Mexico and Korea obtained their membership in 1994 and 1996, respectively). The first four columns use four different measures of corruption: TI, GCR, WDR and ICRG, respectively. In each of these regressions, the extent of capital controls is positively related to the countries' perceived level of corruption.

By using the ICRG corruption measure over 1982-96, we could implement a quasi-fixed effects panel regression where year and region dummies are included as additional regressors. The result is reported in Column 5. The coefficient on the ICRG-corruption measure is smaller than the corresponding one in the cross-section regression in Column 4. But it remains positive and significant at the ten percent level, again consistent with the hypothesis that capital controls are more likely in more corrupt countries.

One may be concerned that the four measures of corruption so far can be tainted by reverse causality. More precisely, since illegal/irregular payments made to circumvent exchange controls are part of the criteria used to assess the degree of corruption, in a very direct sense, countries with a more severe capital controls would also be rated as having more corruption. To deal with this, we employ an instrumental variable approach with variables that are related with the extent of corruption in a country but arguably not directly a consequence of capital controls. Two such variables are considered. The first is a measure of comption in a country's judicial system. When a country's legal system is corrupt, officials who embezzle government tax revenues or otherwise corrupt are less likely to be punished. The second variable is a measure of the degree of democracy (civil liberties and political rights). Democracy enhances accountability. Lack of democracy breeds corruption and embezzlement. Neither legal corruption nor democracy is likely to be directly influenced by the imposition or severity of capital controls.

In the last column of Table 2, we use these two variables as instruments for the GCRcorruption measure. As we can see, the point estimate on corruption is somewhat smaller than the corresponding regression without the IVs (column 2 in Table 2). However, the coefficient remains positive and statistically significant. So this is stronger evidence that more corrupt countries are more likely to impose capital controls. 
In Table 3, we add three regional dummies to the regression (in addition to the OECD membership dummy). Sub-Sahara African countries always have a positive sign in all six regressions (indicating a tendency to have more severe capital controls), whereas East Asian and Latin American countries mostly have a negative sign (indicating a tendency to have less controls). However, for each regional dummy, the coefficient is often insignificantly different from zero in many specifications. For our purpose, the most important observation is that the coefficient on corruption remains positive in all specifications and significant in five out of six specifications (including one in which corruption is instrumented by legal corruption and democracy).

Grilli and Miles-Ferretti (1995) and Miles-Ferretti (1998) have argued that government consumption-to-GDP ratio and government debt-to-GDP ratio are proxies for a government's preference for spending. This could be perfectly consistent with our theoretical model: other things constant, if the government prefers to spend more money, it would want to collect more revenues both from the formal tax channel and simultaneously from the financial repression channel with tightened capital controls ${ }^{4}$. In addition to the government's preference for spending, these authors also propose proxies for the (marginal) cost of capital controls. In particular, they argue that an independent central bank makes it difficult for the government to rely on senioiriage revenue, and hence reduces its incentive to impose capital controls. Following Cukieman, Edwards and Tabellini (1992), they use an index of legal independence of central banks and a count of average annual turnover rate of the central bank governors as two measures of central bank independence. Related to this, the rate of inflation can be a more direct measure of the degree of financial repression the government is willing to exercise. These authors argue further that a government is less likely to impose capital controls if it has been experiencing a current account deficit.

It is useful to note that, while these variables were used by these authors in their regressions, one could argue that most of them are also related to the underlying corruption in a country in a way that is consistent with our model. For example, rather than viewing central bank independence as exogenous, a corrupt country may be more inclined to choose a non-zero inflation rate and at the same time not to have an independent central bank ${ }^{5}$.

\footnotetext{
"In our. model, the equilibrium capital control, $k$, rises with an increase in the relative importance of the public goods in the government's objective function, $\gamma / \delta$. See Proposition 2 in the model section.

See Huang and Wei (2000) for a model and some evidence.
} 
In any case, as a robustness check, we include these variables in our specification as additional regressors. The results are reported in Table 4. Since the number of countries that have non-missing values for these variables is small (among those countries that also have corruption measures), we have between 23-30 observations in the current regressions, less than half than the corresponding regressions in Tables 2 and 3. In the first three columns of Table 4, where a different measure of corruption is used in each column, we see that there is some evidence that countries with high government consumption-to-GDP ratios also tend to impose capital controls. However, there is no systematic support in our regressions that current account deficit, high inflation, and high government debt-to-GDP ratios tend to be associated with more severe capital controls (once corruption and other variables are taken into account). In fact, the signs on the coefficients for inflation and government debt are negative. Importantly, even in this very small sample, corruption measure continues to exhibit a positive and statistically significant sign.

With the ICRG measures of corruption, we experiment with two versions of panel regressions. The first is a quasi-fixed effects regression in which regional dummies in addition to year dummies are included. The second is a random-effects regression in which random country effects in addition to year dummies are included. In the first panel regression, there is some support for a positive association between inflation and capital controls. In both regressions, corruption continues to enter positively and significantly.

Finally, we use the extent of legal corruption and the degree of democracy as instruments for general corruption (the last two columns), we find that the coefficients on corruption are positive and statistically significant. Therefore, even in a small sample such as this and with more control variables, there is robust evidence that more corrupt countries are more likely to impose capital controls.

Since 1997, the IMF's Annual Report on Exchange Arrangements and Exchange Restrictions (AREAER) has given substantially more detailed information on a country's restrictions on up to 50 items of capital account transactions (and similarly detailed information on restrictions on current account transactions). This in principle would enrich our analysis. However, the tradeoff is that such detailed information is only available for 41 countries, many of which do not have data on corruption ratings. Given our already small number of countries in the sample, this could be a significant cost. 
In any case, we relate two separate measures of current account and capital account restrictions based on the detailed information to the measures of corruption in Tables 6 and 7 . The results are interesting. When the dependent variable is current account restrictions, the coefficient for corruption is insignificant in four of five regression (Table 6). However, when the dependent variable is capital account restrictions, corruption has a positive and significant coefficient in three out of five regressions including the one with instrumental variables (Table 7). To the extent that it is primarily the capital account restrictions rather than current account restrictions that help to generate financial repression in the country, these findings are also consistent with our hypothesis.

As a cross-validation, we take a look at our hypothesis from a different perspective. Our central story in the model is a revenue loss mechanism: the government has difficulty in collecting revenue from the formal tax channels and hence has to rely more on capital controls and financial repression. Therefore, one would think that if tax evasion in a country can be measured, it should be positively correlated with corruption. In the Global Competitiveness Report survey, respondents were asked to assess the extent of tax evasion in the country. We use the mean response for each country as a (subjective) measure of the extent of tax evasion. In Table 8, we regress tax evasion on corruption and statutory tax rate. We find that tax evasion is more pervasive in a country with a higher tax rate and a high level of corruption, exactly as our hypothesis would suggest.

\section{Conclusion}

This paper studies bureaucratic corruption as a determinant of capital controls. In our model, capital control is an instrument of financial repression. While it entails efficiency loss for the economy, it also generates implicit revenue for the government. The more severe the bureaucratic corruption in a country, the more difficult it is to collect formal taxes. As a result, the government has to rely more on capital controls/financial repression. In cross-country regressions, we find that more corrupt countries, measured by any of the four corruption indexes, or instrumented by the degree of democracy and legal corruption in a country, do tend to impose more severe capital controls. 
If our story is true, then as countries gradually develop better public institutions along their development trajectory, including reducing bureaucratic corruption over time, they will choose to gradually liberalize their capital accounts. However, a premature removal of capital controls forced upon by external organizations could reduce economic efficiency. 


\section{References}

Ades, Alberto, and Rafael Di Tella, 1999, "Rents, Competition, and Corruption," American Economic Review 89(4): 982-993.

Ades, Alberto, and Rafael Di Tella, 1997, "National Champions and Corruption: Some Unpleasant Interventionist Arithmetic," The Economic Journal, Vol. 107 (443): 1023-42, July.

Altshuler, R., H. Grubert, and T.S. Newlon, 1998, "Has U.S. Investment Abroad Become More Sensitive to Tax Rates?' NBER Working Paper 6382, January.

Alesina, Alberto, Vittorio Grilli, and Gian Maria Milesi-Ferretti, 1994, "The Political Economy of Capital Controls," eds. By Leonardo Leiderman and Assaf Razin, Capital Mobility: The Impact on Consumption, Investment and Growth, Cambridge University Press for the Centre for Economic Policy Research.

Bai, Chong-En, David Li, Yingyi Qian, and Yijiang Wang, 1999, "Limiting Government Predation through Anonymous Banking: A Theory with Evidence from China." Unpublished working paper.

Bardhan, Pranab, 1997, "Corruption and Development: A Review of Issues," Journal of Economic Literature, Vol. XXXV (September): 1320-1346.

Bertolini, Leonardo, and Allen Drazen, 1997, "Capital Account Liberalization as a Signal," American Economic Review, 87(1): 138-154.

Cukierman, A. S. Edwards, and G. Tabellini, 1992, "Measuring the Independence of Central Banks and Its Effects on Policy Outcomes, "World Bank Economic Review, 6, 353-98.

Giovannini, Alberto, and Martha de Melo, 1993, "Government Revenue from Financial Repression," American Economic Review, 83(4): 953-963.

Grilli, Vittorio, and Gian Maria Milesi-Ferretti, 1995, "Economic Determinants of Capital Controls," International Monetary Fund Staff Papers, 42(3): 517-551. September.

Li, Wei, 1999, "Optimal Financial Repression and Asset pricing: Theory and Evidence from China," working paper, Duke University.

Huang, Haizhou, and Shang-Jin Wei, 2000, "Corruption, Inflation, and Central Bank Independence," in preparation, IMF and Harvard University.

Johnston, Barry and Natalia Tamirisa, 1998, "Why Do Countries Use Capital Controls?" IMF Working Paper WP/98/181, December. 
Johnston, Barry, with Mark Swinburne, Alexander Kyei, Bernard Laurens, David Mitchem, Inci Otker, Susana Sosa and Natalia Tamirisa, 1999, Exchange Rate Arrangements and Currency Convertibility: Developments and Issues, Washington: International Monetary Fund.

Kaufmann, Daniel, and Shang-Jin Wei, 1999, "Does 'Grease Money' Speed Up the Wheels of Commerce?” NBER Working Paper 7093.

McKinnon, Ronald, 1973, Money and Finance in Economic Development

Milesi-Ferretti, Gian Maria, 1998, "Why Capital Controls? Theory and Evidence," in Sylvester Eijffinger and Harry Huizinga, eds., Positive Political Economy: Theory and Evidence, Cambridge University Press.

Rodrik, Dani, 1999, "Who Needs Capital-Account Convertibility?" in Should the IMF Pursue Capital Account Convertibility? by Stanley Fischer and others, Essays in International Finance 207, Princeton University, Department of Economics, International Finance Section.

Rodrik, Dani, 1999, "Governing the Global Economy: Does One Architectural Style Fit All?" Brookings Trade Forum, p105-126.

Rodrik, Dani, and Andres Velasco, 1999, "Short-term Flows," The World Bank Annual Bank Conference on Development Economics.

Shaw, Edward S., 1973, Financial Deepening in Economic Development, New York: Oxford University Press.

Tamirisa, Natalia, 1999, "Exchange and Capital Controls as Barriers to Trade," IMF Staff Papers, 46(1): 69-88. March.

Wei, Shang-Jin, 1997, "How Taxing is Corruption on International Investors?" NBER Working Paper 6030, forthcoming, Review of Economics and Statistics. February, 2000.

Wei, Shang-Jin, 1999, "Corruption, Composition of Capital Flows, and Currency Crises," Harvard University and the World Bank.

Wei, Shang-Jin, 2000, "Bribery in the Economies: Grease or Sand?" Harvard University and World Bank.

Wyplosz, Charles, 1986, "Capital Controls and Balance of Payments Crises," Journal of International Money and Finance 5, 167-179. 


\section{Appendix A: Justification of the Bureaucrat's Decision}

In this appendix, we derive the properties of function $S(T, \theta)$ by considering the bureaucrat's decision of choosing S. $\theta$ is a measure of the extent of corruption or the weakness of public institutions. To simplify the derivation, we interpret $\theta^{-1}$ as a measure of the total resources available for monitoring the bureaucrat. Suppose $(\theta T)^{-1}$ units of resources are devoted to the monitoring of each unit of tax revenue. Furthermore, the probability that the bureaucrat is found stealing from any given unit of tax revenue is $\psi(\mathrm{S} / \mathrm{T})(\theta \mathrm{T})^{-1}$, where $\psi$ is a convex function and $\mathrm{S} / \mathrm{T}$ is the proportion of each unit of tax revenue being stolen. Finally, the penalty imposed on the bureaucrat for being caught stealing from a unit of tax revenue is $\mathrm{C}$. For each unit of tax revenue, the bureaucrat steals $\mathrm{S} / \mathrm{T}$, and the expected cost (penalty) of his stealing is $\mathrm{C} \psi(\mathrm{S} / \mathrm{T})(\theta \mathrm{T})^{-}$ '. Then the bureaucrat's total expected payoff is

$$
\mathrm{T}\left[\mathrm{S} / \mathrm{T}-\mathrm{C} \psi(\mathrm{S} / \mathrm{T})(\theta \mathrm{T})^{-1}\right]=\mathrm{S}-\mathrm{TC} \psi(\mathrm{S} / \mathrm{T})(\theta \mathrm{T})^{-1} .
$$

Suppose the bureaucrat chooses $\mathrm{S}$ to maximize the above expression. Then his optimal choice of $\mathrm{S}$ is given by the first-order condition

$$
1-\mathrm{C} \psi^{\prime}(\mathrm{S} / \mathrm{T})(\theta \mathrm{T})^{-1}=0 .
$$

Consequently, the optimal $\mathrm{S}$ is

$$
\mathrm{S}=\mathrm{T} \tau\left(\theta \mathrm{TC}^{-1}\right) \text {, }
$$

where $\tau$ is the inverse function of $\psi^{\prime}$ and is increasing. The derivative of $S$ with respect to $\theta$ is

$$
\mathrm{S}_{\theta}=\mathrm{T} \tau^{\prime}\left(\theta \mathrm{TC} \mathrm{C}^{-1}\right) \mathrm{TC}^{-1}>0 .
$$

The derivative of $S$ with respect to $T$ is

$$
\mathrm{S}_{\mathrm{T}}=\tau+\mathrm{T} \tau^{\prime} \theta \mathrm{C}^{-1}>0 .
$$

Differentiate the above expression and rearrange. Then,

$$
\mathrm{S}_{\mathrm{TT}}=\theta \mathrm{C}^{-1} \tau^{\prime}(z)\left[2+z \tau^{\prime \prime}(z) / \tau^{\prime}(z)\right],
$$

where $z=\theta T C^{-1}$. Suppose function $\tau$ satisfies the condition that

$$
2+z \tau^{\prime \prime}(z) / \tau^{\prime}(z)>0,
$$

which holds for $\tau(z)=A(z+b)^{\beta}+C_{1}$ and for $\tau(z)=A e^{B z}+C_{2}$, for any $A, B, b, C_{1}, C_{2}$, and $\beta>0$. Then, $S_{T T}>0$, i.e., $S$ is convex in T. Similarly, we can prove that $S_{T \theta}>0$ under condition (4). 


\section{Appendix B: Proofs of Propositions 1 and 2}

\section{Proof of Proposition 1}

Differentiate equation (1) in Lemma 1 with respect to $\theta$. Then

$$
\mathrm{S}_{\mathrm{TT}} \mathrm{T}_{\theta}+\mathrm{S}_{\mathrm{T} \theta}=0 \text {, }
$$

which implies

$$
\mathrm{T}_{\theta}=-\mathrm{S}_{\mathrm{T} \theta} / \mathrm{S}_{\mathrm{TT}}<0 \text {. }
$$

Differentiate equation (2) in Lemma 1 with respect to $\theta$. Then

$$
\mathrm{T}_{\theta}-\mathrm{S}_{\mathrm{T}} \mathrm{T}_{\theta}-\mathrm{S}_{\theta}+\phi \rho\left(\mathrm{Y}_{0}-\mathrm{T}\right) \mathrm{k}_{\theta}-\phi \rho k \mathrm{~T}_{\theta}=0,
$$

or

$$
\phi \rho\left(\mathrm{Y}_{0}-\mathrm{T}\right) \mathrm{k}_{\theta}=\mathrm{S}_{\theta}-\mathrm{T}_{\theta}\left(1-\mathrm{S}_{\mathrm{T}}-\phi \rho \mathrm{k}\right) .
$$

By equation (1),

$$
1-\mathrm{S}_{\mathrm{T}}-\phi \rho \mathrm{k}=\phi\left(\mathrm{r}^{*}-\rho \mathrm{k}\right)=\phi \mathrm{R}_{\mathrm{d}}>0 .
$$

Since $S_{\theta}>0$ and $T_{\theta}<0$, (3) implies

$$
\mathrm{k}_{\theta}>0 \text {. }
$$

\section{Proof of Proposition 2}

(i) From equation (1), T is independent of $\rho$. Then, equation (2) implies that $\rho \mathrm{k}$ is independent of $\rho$, which in tum implies that $k$ decreases with $\rho$.

(ii) Differentiating equation (1) with respect to $\phi$ yields

$$
\mathrm{T}_{\phi}=-\mathrm{r} * / \mathrm{S}_{\mathrm{TT}}<0 .
$$

Differentiating equation (2) with respect to $\phi$ and rearranging yield

$$
\phi \rho\left(\mathrm{Y}_{0}-\mathrm{T}\right) \mathrm{k}_{\phi}=-\rho \mathrm{k}\left(\mathrm{Y}_{0}-\mathrm{T}\right)-\mathrm{T}_{\phi}\left(1-\mathrm{S}_{\mathrm{T}}-\phi \rho \mathrm{k}\right)-\left\{\left[\left(\mathrm{f}^{\prime}\right)^{-1}\right]^{\prime}(\delta / \gamma \phi)\right\}\left(\delta / \gamma \phi^{2}\right) .
$$

On the right hand side, the first term is negative, the second term is positive as $T_{\phi}<0$ and by the proof of Proposition 1, and the third term is also positive because $f^{\prime}$ is a decreasing function. Therefore, the sign of $k_{\phi}$ whether the first term dominates, or is dominated by, the other two terms.

(iii) By equation (1), $T$ is independent of $\gamma$ and $\delta$. The right hand side of equation (2) increases with $\gamma$ and decreases with $\delta$ as $f^{\prime}$ is a decreasing function. Therefore, $k$ increases with $\gamma$ and decreases with $\delta$. 
(iv) Both equations (1) and (2) are independent of $\rho_{f}$ and $\sigma^{2}$. Therefore, the optimal $\mathrm{T}$ and $\mathrm{k}$ are both independent of $\rho_{\mathrm{f}}$ and $\sigma^{2}$. $\quad$ Q.E.D.

\section{Appendix C: Alternative Assumption on the Implicit Revenue from Financial Repression}

In this appendix, we consider the alternative assumption that the implicit tax revenue from financial repression is $\phi \rho \mathrm{k}(1-\alpha)\left(\mathrm{Y}_{0}-\mathrm{T}\right)$. With this assumption, the amount of the government's usable fiscal resources is

$$
Z=[T-S(T, \theta)]+\left[\phi \rho k(1-\alpha)\left(Y_{0}-\mathrm{T}\right)\right] .
$$

The private investor's choice of $\alpha$ is not affected by this alternative assumption and is still $\alpha^{*}$. Given

$$
\alpha=\alpha^{*}=\rho_{f}\left[\delta \mathrm{k} \sigma^{2}\left(\mathrm{Y}_{0}-\mathrm{T}\right)\right]
$$

we have

$$
k \alpha^{*}\left(Y_{0}-T\right)=\rho_{f}\left(\delta \alpha^{2}\right)
$$

and then

$$
Z=T-S(T, \theta)+\phi \rho k\left(Y_{0}-T\right)-\phi \rho \rho_{f}^{\prime}\left(\delta \sigma^{2}\right),
$$

which differs from the value of $Z$ under the original assumption about the implicit tax revenue only by a constant term $-\phi \rho \rho_{f} f\left(\delta \sigma^{2}\right)$. Similar to the proof of Lemma 1, we can show that

Lemma 1': The optimal $T$ is determined by

$$
S_{T}(T, \theta)=I-\phi r^{*}
$$

and the optimal $k$ is determined by

$$
T-S(T, \theta)+\phi \rho k\left(Y_{0}-T\right)=\left(f^{\prime}\right)^{-1}[\delta /(\gamma \phi)]+\phi \rho \rho f^{\prime}\left(\delta \sigma^{2}\right) .
$$

\section{Comparative Statics:}

Proposition 1 is about comparative statics with respect to $\theta$. Lemma 1' and Lemma 1 differ only by the term $\phi \rho \rho_{f} /\left(\delta \sigma^{2}\right)$, which is independent of $\theta$. Therefore, Proposition 1 continues to hold under the alternative assumption about the implicit tax revenue. 
Parts (i), (ii), and (iii) of Proposition 2 remain the same. However, the result about $k$ in part (iv) changes with the alternative assumption about the implicit tax revenue; previously, the optimal $\mathrm{k}$ was independent of $\rho_{\mathrm{f}}$ and $\sigma^{2}$, but under the alternative assumption, the optimal $\mathrm{k}$ increases with $\rho_{\mathrm{f}}$ and decreases with $\sigma^{2}$. Specifically, we have

Proposition 2': (i) The optimal tax $T$ is independent of the degree of risk aversion $\rho$ but the optimal capital control $k$ decreases with $\rho$. (ii) The optimal tax $T$ decreases with $\phi$ but the relationship between the optimal $k$ and $\phi$ is ambiguous. (iii) The optimal $T$ is independent of $\gamma$ and $\delta$, but the optimal $k$ increases with $\gamma$ and decreases with $\delta$, where $\gamma$ is the importance of the public good in the representative private investor's utility while $\delta$ is that of private consumption. (iv) The optimal $T$ is independent of $\rho_{f}$ and $\sigma^{2}$. The optimal $k$ increases with $\rho_{f}$ and decreases with $\sigma^{2}$.

The proof of Proposition 2' is similar to that of Proposition 2, except that for (i) is different. By equation ( $\left.l^{\prime}\right), T$ is still independent of $\rho$. By equation (2'),

$$
\phi \rho\left[k\left(Y_{0}-T\right)-\rho_{\mathrm{f}}\left(\delta \sigma^{2}\right)\right]=Z^{*}-\mathrm{T}+\mathrm{S}(\mathrm{T}, \theta) .
$$

On the left hand side,

$$
k\left(Y_{0}-T\right)-\rho_{f} f\left(\delta \sigma^{2}\right)=k(1-\alpha *)\left(Y_{0}-T\right)>0 .
$$

Therefore, $Z^{*}-T+S(T, \theta)$ is also positive. Furthermore, $Z^{*}-T+S(T, \theta)$ is independent of $\rho$. Then,

$$
k\left(Y_{0}-T\right)-\rho_{f}\left(\delta \sigma^{2}\right)=\left[Z^{*}-T+S(T, \theta)\right] / \phi \rho
$$

decreases with $\rho$, which implies that $k$ decreases with $\rho$.

The intuition for Proposition 2 ' is the same as that for Proposition 2, except that for part (iv) of the propositions. Under the alternative assumption about the implicit tax revenue, a higher $\rho_{\mathrm{f}}$ (premium of capital flight) or a lower $\sigma^{2}$ (risk of capital flight) reduces the amount of domestic capital that the government can implicitly tax through financial repression. In order to maintain the level of this source of revenue, the government has to increase the degree of financial repression, which is positively related to capital control. Therefore, the government responds to a higher $\rho_{\mathrm{f}}$ or a lower $\sigma^{2}$ by choosing a higher $\mathrm{k}$. 


\section{Appendix D: Data Documentation}

1. We used two measures of Capital Control. The first one is a based on the presence or absence of restrictions on foreign exchange transactions in five categories defined in the IMF's Annual Report on Exchange Arrangements and Exchange Restrictions (AREAER), various issues. Courtesy of Milesi-Ferretti for data on the last three of the five categories.

\section{Multiple Exchange Rates: mulex}

Source: Exchange arrangements and exchange restrictions annual report 1997/1998, IMF. Dual or multiple exchange rates.

Assign 1 if the specified practice is a feature of the exchange system, 0 otherwise. If missing replaced with $1995 / 96$ data.

\section{Payment Arrears or Bilateral Payment Arrangement: payarr \& bipay}

Source: Exchange arrangements and exchange restrictions annual report 1997/1998, IMF. Arrangements for payments and receipts: payment arrears or bilateral payment arrangements. Assign 1 if any of the specified practice is present, 0 otherwise.

If missing replaced with $1995 / 96$ data.

\section{Controls on Payments for Invisible Transactions and Current Transfers: rescur} Source: Exchange arrangements and exchange restrictions annual report 1997/1998, IMF. Control on payments for invisible transactions and current transfers Assign 1 if the specified practice is present for either items, 0 otherwise. If missing replaced with $1995 / 96$ data.

\section{Controls on Proceeds from Exports and/or Invisible Transactions: resexp}

Source: Exchange arrangements and exchange restrictions annual report 1997/1998, IMF. Proceeds from exports and/or invisible transactions.

2 items: repatriation requirements, surrender requirements

Assign 1 if the specified practice is a feature of the exchange system for either items, 0 otherwise.

- Among the two items, if one if missing and the other one is 1 , assign 1 .

- Among the two items, if one is missing and the other is 0 , assign 0 , countries include: Antigua and Barbuda

\section{Controls on Capital Account Transactions: cap}

Source: Exchange arrangements and exchange restrictions annual report 1997/1998, IMF. Controls on capital transactions:

1997 has Controls on 11 items, 1996 has only the first 10 items.

1. Capital market securities

2. Money market instruments

3. Collective investment securities

4. Derivatives and other instruments

5. Commercial credits

6. Financial credits

7. Guarantees, sureties, and financial backup facilities 
8. Direct investment

9. Liquidation of direct investment

10. Real estate transactions

11. Personal capital movements

1997 data: Assign 1 for each item if the sum of the features $>3,0$ otherwise. Treat as missing if there are $>4$ missing categories.

If there are $<=3$ missing categories, we assign the most common ratings in the rest of the categories to replace the missing values. These countries are: Algeria, Angola, Barbados, Belize, Bhutan, Bosnia and Herzegovina, Botswana, Burundi, Cameroon, Central African Republic, Chad, Columbia, Comoros, Congo, Rep. of, Costa Rica, Dominica, Equatorial Guinea, Gabon, Gambia, Georgia, Grenada, Honduras, Jamaica, Latvia, Lesotho, Liberia, Libya, Lithuania, Maldives, Mali, Mauritania, Mongolia, Oman, Papua New Guinea, Qatar, Romania, Russia, Sit. Kitts and Nevis, St. Lucia, St. Vincent and the Grenadines, Saudi Arabia, Senegal, Seychelles, Somalia, Sudan, Syrian, Turkmenistan, Uzbekistan, Zimbabwe

1996 data: Only look at the first 10 items: Assign 1 for each item if the sum of features $>3,0$ otherwise. Treat as missing if there are $>4$ missing values.

1995 and before:

Used the data on Southern Yemen (data closer to later data) for Yemen Rep.

Used the data on Belgium-Luxembourg for both Belgium and Luxembourg.

1991 and before:

Used the data on Czechoslovakia for Czech and Slovakia:

Used the data on former Yugoslavia for Yugoslavia, FDR;

Before 1989: Used the data on West Germany for Germany.

Second measure of Capital Control is more detailed coding of restrictions on close to 50 items of capital account transactions (together with a similarly detailed coding of current account restrictions), computed by Natalia Tamirisa for Tamirisa (1999) and Johnston and etc. (1999), based on the IMF's Annual Report on Exchange Arrangements and Exchange Restrictions (AREAER), 1997. Courtesy of Natalia Tamirisa.

\section{Measures of Corruption}

\section{ICRG Index}

Corruption in Government from the International Country Risk Guide.

Bahamas, Malta, Mongolia, Yugoslavia, FR (Serb./Mont.): usd the data from 1986 for 1985; Bahamas, Burkina Faso, Congo, Rep., Gambia, The, Guinea-Bissau, Korea, Dem. Rep., Malta, Mongolia, Niger, Sierra Leone, Yemen, Rep., Yugoslavia, FR(Serb.Mont.), used the data from 1985/86 for 1984. Original scale 0-6, Lower point totals indicate higher risk, rescale as 6 original score. 


\section{TI Index}

Source: Transparency International (http://www.gwdg.de/ uwvw/icr.htm), used 1998 index, which will be the ranking for 1997.

Transparency International has adopted the approach of a composite index. It is a "poll of polls". It consists of credible surveys using different sampling frames and varying methodologies. The 1998 CPI includes data from the Economist Intelligence Unit (Country Risk Service and Country Forecasts), Gallup International (50th Anniversary Survey), the Institute for Management Development (World Competitiveness Yearbook), the Political \& Economic Risk Consultancy (Asian Intelligence Issue), the Political Risk Services (International Country Risk Guide), World Development Report (Private Sector Survey) and the World Economic Forum (Global Competitiveness Report), etc. Note: TI has corruption indexes for earlier years as well. However, the underlying methodology changes every year which makes inter-year comparison misleading. We re-scaled the TI index by subtracting the original numbers from 10 so that a large number implies more corruption.

\section{GCR Index}

Source: Appendix to Kaufmann and Wei, "Does 'Grease Money' speed up the wheels of commerce". NBER working paper 7093. Original source: Global competitiveness report 96, 97

GCR are surveys conducted by the World Economic Forum and Harvard Institute for International Development for the 1996 and 1997 Global Competitiveness Reports, respectively. GCR surveys are on 1-7 scales. Corruption rating for a country in this table is the average of all individual responses for that country. In original surveys, a low number means more corruption, the rating is re-scaled as 8 - original rating. GCR97 is published in 1997 and the ranking is for 1996.

\section{WDR Index}

Source: Appendix to Kaufmann and Wei, "Does 'Grease Money' speed up the wheels of commerce" NBER working paper 7093. Original source: 1997 World Development Report, survey conducted by the World Bank for its 1997 World Development Report. The rating is then for 1996.

WDR surveys are on 1-6 scales. Corruption rating for a country in this table is the average of all individual responses for that country. In original surveys, a low number means more corruption, the rating is re-scaled as 7 - original rating.

\section{Instrumental Variables for Corruption}

\section{Civil liberty and political freedom (1993)}

Source: Freedom House, Freedom in the World, Freedom House Survey Team, 1993-1994

CIV is the abbreviation for civil liberties index. Liberties index measures the extent to which people are able to express their opinion openly without fears of reprisals and are protected in doing so by an independent judiciary. Though this index reflects rights to organize and demonstrate as well as freedom of religion, education, travel and other personal rights; more weight was given to those liberties that are most directly related to the expression of political rights. This variable is an index and not in logs. 
POL is the abbreviation for political right index. Political rights index measures rights to participate meaningfully in the political process on a scale of one to seven where lower numbers indicate greater political rights (see Gastil, 1989). A high ranking country must have a fully operating electoral procedure, usually including a significant opposition vote. It is likely to have had a recent change of govermment from one party to another, an absence of foreign domination, decentralized political power and a consensus that allows all segments of the population some power. The index was constructed on the basis of satisfaction of the above and other related criteria by the countries in question. This variable is an index and not in logs.

Both Index range from 1 to 7 . Smaller number means higher degree of freedom. Democracy is defined as (7-civ) $+(7$-pol) .

\section{Corruption in Judicial System}

Source, "lack of legal corruption," survey in 1996 for the Global Competitiveness Report 1997. Question 8.09 Legal corruption, "Irregular payments to judges or other officials involved in the enforcement and execution of judgements are not common and do not influence the outcome of court proceedings" ( $1=$ strongly disagree, $7=$ strongly agree).

Rescaled 7 - original score Thus a smaller number means less corrupt judicial system.

\section{Tax Evasion and Tax Rates}

\section{Tax Evasion}

Source: survey (in 1996) for the Global Competitiveness Report 1997

2.10 Tax evasion, Tax evasion is minimal in your country. ( $1=$ strongly disagree, $7=$ strongly agree). Re-scaled as 7 - original score

\section{Statutory Corporate Tax Rates}

Courtesy of Altshuler for providing the data used in Altshuler, Grubert and Newlon (1998) Notes: 1. For Bermuda, effective tax rate was used instead of statutory rates. The statutory rate for Bermuda was zero, but the effective rate was positive. 2. In some cases judgement was made on the appropriate rate due to the presence of tax holidays.

\section{Other Variables}

\section{Current Account Surplus}

Source: World Bank Sima/GDF \& WDI Central

Current account balance (\% of GDP)1984-1997, in cross section regression used the average of 1984-96.

\section{Government Consumption}

Source: World Bank Sima/GDF \& WDI Central

General government consumption (\% of GDP)

1984-1997, in cross section regression used the average of 1984-96.

\section{Government Debt}

Source: World Bank Sima/GDF \& WDI Central

Central government debt, total (\% of GDP) 
Table 1a: Summary Statistics

\begin{tabular}{lccccc} 
& Obs & Mean & Std. Dev. & Min & Max \\
Aggregate capital control & 177 & 2.44 & 1.57 & 0 & 5 \\
Current account controls & 40 & 0.13 & 0.10 & 0.01 & 0.33 \\
Capital account controls & 40 & 0.38 & 0.30 & 0.01 & 0.95 \\
Comption - TI & 84 & 5.10 & 2.41 & 0 & 8.6 \\
Corruption - WDR & 72 & 3.21 & 0.91 & 1 & 4.6 \\
Corruption - ICRG & 122 & 2.57 & 1.28 & 0 & 6 \\
Corruption - GCR & 58 & 3.40 & 1.42 & 1.3 & 5.5 \\
Legal Corruption - GCR & 53 & 1.70 & 1.47 & 0 & 4.53 \\
Democracy & 175 & 6.62 & 3.97 & 0 & 12 \\
\hline Note: Democracy is constructed by summing
\end{tabular}

Note: Democracy is constructed by summing up the political rights and civil liberties indexes.

Table 1b: Pairwise Correlation

\begin{tabular}{|c|c|c|c|c|c|c|c|c|}
\hline & \multicolumn{3}{|c|}{ Capital Controls } & \multicolumn{4}{|c|}{ Corruption } & \multirow{2}{*}{$\begin{array}{l}\text { Legal } \\
\text { Corruption }\end{array}$} \\
\hline & aggregate & $\mathrm{CA}$ & $\mathrm{KA}$ & $\mathrm{TI}$ & WDR & ICRG & GCR & \\
\hline Current account control & 0.78 & 1 & & & & & & \\
\hline Capital account control & 0.88 & 0.83 & 1 & & & & & \\
\hline Corruption - TI & 0.58 & 0.53 & 0.52 & 1 & & & & \\
\hline Corruption - WDR & 0.62 & 0.55 & 0.65 & 0.86 & 1 & & & \\
\hline Corruption - ICRG & 0.44 & 0.49 & 0.43 & 0.85 & 0.55 & 1 & & \\
\hline Corruption - GCR & 0.56 & 0.52 & 0.60 & 0.87 & 0.83 & 0.65 & 1 & \\
\hline Legal corruption & 0.55 & 0.50 & 0.58 & 0.89 & 0.77 & 0.80 & 0.80 & 1 \\
\hline Democracy & -0.44 & -0.57 & -0.49 & -0.68 & -0.50 & -0.66 & -0.57 & -0.67 \\
\hline
\end{tabular}


Table 2: Bureaucratic Corruption and Capital Controls

\begin{tabular}{|c|c|c|c|c|c|c|}
\hline \multicolumn{7}{|c|}{ Dependent Variable $=$ capital control } \\
\hline Specification & & Orc & ed probit & & Panel & IV \\
\hline Corruption measure & TI & . GCR97 & WDR97 & ICRG96 & ICRG & GCR97 \\
\hline Corruption & $\begin{array}{c}0.275^{* *} \\
(0.071)\end{array}$ & $\begin{array}{c}0.440^{* *} \\
(0.129)\end{array}$ & $\begin{array}{c}0.834^{* *} \\
(0.189)\end{array}$ & $\begin{array}{l}0.239^{* *} \\
(0.101)\end{array}$ & $\begin{array}{c}0.079 * * \\
(0.036)\end{array}$ & $\begin{array}{c}0.415^{* *} \\
(0.183)\end{array}$ \\
\hline OECD & $\begin{array}{c}-0.665^{* *} \\
(0.333)\end{array}$ & $\begin{array}{c}-0.747^{* *} \\
(0.344)\end{array}$ & $\begin{array}{c}-0.465 \\
(0.367)\end{array}$ & $\begin{array}{c}-1.051^{* *} \\
(0.307)\end{array}$ & $\begin{array}{c}-2.180^{* *} \\
(0.123)\end{array}$ & $\begin{array}{c}-0.979^{* *} \\
(0.401)\end{array}$ \\
\hline $\mathrm{R}^{2}$ & 0.15 & 0.16 & 0.15 & 0.10 & 0.29 & 0.16 \\
\hline No. of Obs & 83 & 57 & 71 & 120 & 1629 & 51 \\
\hline
\end{tabular}

1. White-robust standard errors in brackets. **, " and \# denote significant at the $5 \%, 10 \%$ and the $15 \%$ levels, respectively,

2. Pseudo $\mathrm{R}^{2}$ for ordered probit and IV regressions. Adjusted $\mathrm{R}^{2}$ for panel regression (LSDV, fixed effects with year dummies).

3. Estimates on the constant and the cutoff parameters are not reported.

\section{Table 3: Corruption and Capital Controls After Adding Regional Dummies}

\begin{tabular}{|c|c|c|c|c|c|c|}
\hline \multicolumn{7}{|c|}{ Dependent Variable $=$ capital control } \\
\hline \multirow{2}{*}{$\begin{array}{l}\text { Specification } \\
\text { Corruption measure }\end{array}$} & \multicolumn{4}{|c|}{ ordered probit } & \multirow{2}{*}{$\begin{array}{l}\text { panel } \\
\text { ICRG }\end{array}$} & \multirow{2}{*}{$\begin{array}{c}\text { IV } \\
\text { GCR97 }\end{array}$} \\
\hline & TI & GCR97 & WDR97 & ICRG96 & & \\
\hline Corruption & $\begin{array}{c}0.308^{* *} \\
(0.074)\end{array}$ & $\begin{array}{l}0.501^{* *} \\
(0.135)\end{array}$ & $\begin{array}{l}0.880^{* *} \\
(0.201)\end{array}$ & $\begin{array}{c}0.210^{* *} \\
(0.103)\end{array}$ & $\begin{array}{c}0.030 \\
(0.035)\end{array}$ & $\begin{array}{c}0.539 * * \\
(0.204)\end{array}$ \\
\hline OECD & $\begin{array}{c}-0.795 * * \\
(0.362)\end{array}$ & $\begin{array}{l}-0.845^{* *} \\
(0.394)\end{array}$ & $\begin{array}{c}-0.309 \\
(0.406)\end{array}$ & $\begin{array}{c}-1.078^{* *} \\
(0.321)\end{array}$ & $\begin{array}{c}-1.926^{* *} \\
(0.125)\end{array}$ & $\begin{array}{c}-0.887^{* *} \\
(0.432)\end{array}$ \\
\hline $\begin{array}{l}\text { Sub-Sahara } \\
\text { Africa }\end{array}$ & $\begin{array}{c}0.090 \\
(0.365)\end{array}$ & $\begin{array}{c}0.906 \\
(0.807)\end{array}$ & $\begin{array}{l}0.515 \# \\
(0.325)\end{array}$ & $\begin{array}{l}0.540^{* *} \\
(0.269)\end{array}$ & $\begin{array}{l}0.857^{* *} \\
(0.103)\end{array}$ & $\begin{array}{c}1.020 \\
(0.820)\end{array}$ \\
\hline $\begin{array}{l}\text { East Asia and } \\
\text { Pacific }\end{array}$ & $\begin{array}{l}-0.242 \\
(0.373)\end{array}$ & $\begin{array}{l}-0.257 \\
(0.412)\end{array}$ & $\begin{array}{c}0.302 \\
(0.546)\end{array}$ & $\begin{array}{c}-0.030 \\
(0.324)\end{array}$ & $\begin{array}{c}-0.820^{* *} \\
(0.128)\end{array}$ & $\begin{array}{l}-0.201 \\
(0.420)\end{array}$ \\
\hline Latin America & $\begin{array}{c}-0.789 * * \\
(0.356)\end{array}$ & $\begin{array}{c}-0.498 \\
(0.444)\end{array}$ & $\begin{array}{c}-0.597 \\
(0.418)\end{array}$ & $\begin{array}{c}-0.519^{*} \\
(0.289)\end{array}$ & $\begin{array}{l}0.222^{* *} \\
(0.111)\end{array}$ & $\begin{array}{c}-0.402 \\
(0.529)\end{array}$ \\
\hline$R^{2}$ & 0.18 & 0.18 & 0.18 & 0.13 & 0.35 & 0.18 \\
\hline No. of Obs & 83 & 57 & 71 & 120 & 1629 & 51 \\
\hline
\end{tabular}


Table 4: Corruption and Capital Controls with Additional Control Variables

\begin{tabular}{|c|c|c|c|c|c|c|c|}
\hline \multicolumn{8}{|c|}{ Dependent Variable: capital control } \\
\hline \multirow{2}{*}{$\begin{array}{l}\text { Specification } \\
\text { Corruption measure }\end{array}$} & \multicolumn{3}{|c|}{ ordered probit } & \multicolumn{2}{|c|}{ Panel } & \multicolumn{2}{|c|}{ IV } \\
\hline & $\mathrm{TI}$ & GCR & ICRG96 & ICRG & ICRG & GCR & GCR \\
\hline Corruption & $\begin{array}{l}0.567^{* *} \\
(0.175)\end{array}$ & $\begin{array}{l}2.491^{* *} \\
(0.994)\end{array}$ & $\begin{array}{l}0.723 * * \\
(0.306)\end{array}$ & $\begin{array}{l}0.124 \# \\
(0.083)\end{array}$ & $\begin{array}{l}0.110^{*} \\
(0.067)\end{array}$ & $\begin{array}{c}0.810^{*} \\
(0.489)\end{array}$ & $\begin{array}{l}0.821^{* *} \\
(0.396)\end{array}$ \\
\hline $\begin{array}{l}\text { Current Account } \\
\text { Balance/GDP }\end{array}$ & $\begin{array}{c}0.037 \\
(0.064)\end{array}$ & $\begin{array}{l}-0.052 \\
(0.188)\end{array}$ & $\begin{array}{l}-0.008 \\
(0.060)\end{array}$ & $\begin{array}{c}-0.057 * * \\
(0.018)\end{array}$ & $\begin{array}{c}-0.020^{* *} \\
(0.009)\end{array}$ & $\begin{array}{l}-0.183 \# \\
(0.117)\end{array}$ & $\begin{array}{l}-0.072 \\
(0.095)\end{array}$ \\
\hline $\begin{array}{l}\text { Government } \\
\text { Consumption/GDP }\end{array}$ & $\begin{array}{l}0.146^{* *} \\
(0.071)\end{array}$ & $\begin{array}{l}0.459 * * \\
(0.203)\end{array}$ & $\begin{array}{c}0.084 \\
(0.061)\end{array}$ & $\begin{array}{c}-0.085^{* *} \\
(0.024)\end{array}$ & $\begin{array}{c}0.016 \\
(0.024)\end{array}$ & $\begin{array}{c}0.099 \\
(0.092)\end{array}$ & $\begin{array}{l}0.131 \# \\
(0.086)\end{array}$ \\
\hline $\begin{array}{l}\text { Government } \\
\text { Debt/GDP }\end{array}$ & $\begin{array}{c}-0.013^{* *} \\
(0.006)\end{array}$ & $\begin{array}{l}-0.017 \\
(0.013)\end{array}$ & $\begin{array}{c}-0.011^{* *} \\
(0.006)\end{array}$ & $\begin{array}{l}-0.004^{*} \\
(0.002)\end{array}$ & $\begin{array}{l}-0.001 \\
(0.002)\end{array}$ & $\begin{array}{l}-0.005 \\
(0.008)\end{array}$ & $\begin{array}{l}-0.001 \\
(0.008)\end{array}$ \\
\hline Inflation & $\begin{array}{l}-0.001 \\
(0.001)\end{array}$ & $\begin{array}{l}-0.004 \\
(0.004)\end{array}$ & $\begin{array}{l}-0.001 \\
(0.001)\end{array}$ & $\begin{array}{l}0.010^{* *} \\
(0.002)\end{array}$ & $\begin{array}{l}-0.0003 \\
(0.001)\end{array}$ & $\begin{array}{l}-0.002 \\
(0.001)\end{array}$ & $\begin{array}{l}-0.002 \\
(0.001)\end{array}$ \\
\hline $\begin{array}{l}\text { Central bank legal } \\
\text { Independence }\end{array}$ & $\begin{array}{l}-0.150 \\
(1.881)\end{array}$ & $\begin{array}{l}-4.238 \\
(4.173)\end{array}$ & $\begin{array}{c}1.322 \\
(2.067)\end{array}$ & $\begin{array}{c}-2.123 * * \\
(0.874)\end{array}$ & $\begin{array}{l}-1.642 \\
(2.801)\end{array}$ & $\begin{array}{l}-3.430 \\
(2.608)\end{array}$ & $\begin{array}{l}-1.970 \\
(2.260)\end{array}$ \\
\hline $\begin{array}{l}\text { Central bankers } \\
\text { Turnover }\end{array}$ & $\begin{array}{l}5.577^{* *} \\
(1.738)\end{array}$ & $\begin{array}{c}21.868^{* *} \\
(7.832)\end{array}$ & $\begin{array}{l}3.584^{* *} \\
(1.471)\end{array}$ & $\begin{array}{l}1.012 \# \\
(0.627)\end{array}$ & $\begin{array}{l}3.271^{* *} \\
(1.375)\end{array}$ & $\begin{array}{l}8.946^{* *} \\
(2.823)\end{array}$ & $\begin{array}{l}6.875^{* *} \\
(1.932)\end{array}$ \\
\hline OECD & $\begin{array}{l}-0.963 \\
(0.691)\end{array}$ & $\begin{array}{l}-0.931 \\
(1.462)\end{array}$ & $\begin{array}{c}-1.546^{* *} \\
(0.639)\end{array}$ & $\begin{array}{c}-1.669^{* *} \\
(0.290)\end{array}$ & & $\begin{array}{l}-1.134 \\
(0.856)\end{array}$ & \\
\hline $\begin{array}{l}\text { Sub-Sahara } \\
\text { Africa }\end{array}$ & $\begin{array}{c}0.374 \\
(0.769)\end{array}$ & & $\begin{array}{l}-0.043 \\
(0.704)\end{array}$ & $\begin{array}{c}-0.067 \\
(0.285)\end{array}$ & & & \\
\hline $\begin{array}{l}\text { East Asia and } \\
\text { Pacific }\end{array}$ & $\begin{array}{l}-0.513 \\
(0.760)\end{array}$ & $\begin{array}{l}-1.169 \\
(1.434)\end{array}$ & $\begin{array}{l}-1.212^{*} \\
(0.721)\end{array}$ & $\begin{array}{c}-2.789 * * \\
(0.238)\end{array}$ & & $\begin{array}{l}-1.720^{*} \\
(0.909)\end{array}$ & \\
\hline Latin America & $\begin{array}{l}-0.601 \\
(0.919)\end{array}$ & $\begin{array}{c}0.514 \\
(1.595)\end{array}$ & $\begin{array}{l}-1.048 \\
(0.899)\end{array}$ & $\begin{array}{c}-1.708^{* *} \\
(0.357)\end{array}$ & & $\begin{array}{l}-1.851 \\
(1.380)\end{array}$ & \\
\hline $\mathrm{R}^{2}$ & 0.39 & 0.66 & 0.33 & 0.65 & 0.13 & 0.36 & 0.29 \\
\hline No. of Obs & 32 & 25 & 33 & 167 & 167 & 25 & 25 \\
\hline
\end{tabular}


Table 5: Effect of a Rise in Corruption on Capital Controls

(Based on the last regression in Table 3)

$\begin{array}{cccccc}\text { P0 } & \text { P1 } & \text { P2 } & \text { P3 } & \text { P4 } & \text { P5 } \\ & & & & & \\ 0.13 & 0.26 & 0.15 & 0.31 & 0.10 & 0.04 \\ 0.64 & 0.25 & 0.06 & 0.05 & 0.01 & 0.00\end{array}$

Corruption $=4.3$ (e.g. Ukrain)

Corruption $=1.6$ (e.g. Singapore)

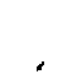

(Based on the second to the last regression

in Table 4)

\begin{tabular}{lllllll} 
Corruption $=4.3$ (e.g. Ukrain) & 0.04 & 0.28 & 0.34 & 0.33 & 0.01 & 0.00 \\
Corruption $=1.6$ (e.g. Singapore) & 0.68 & 0.28 & 0.04 & 0.00 & 0.00 & 0.00 \\
\hline
\end{tabular}

Note: P0, P1, .., P5 denote the probability that the aggregate capital control index $=0,1, \ldots, 5$, respectively. Used average values for explanatory variabies other than corruption.

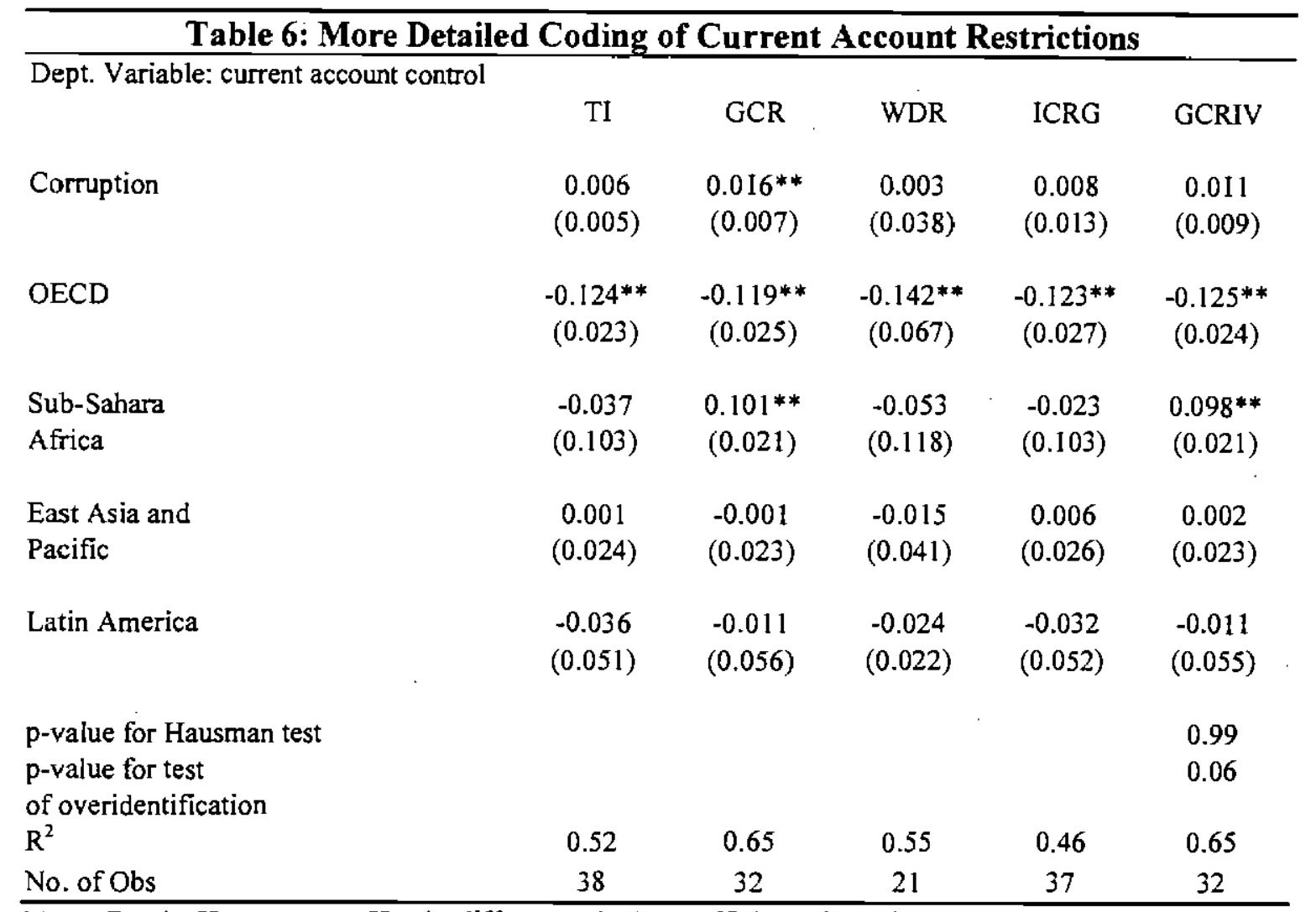

Note: For the Hausman test, Ho: the differences in the coefficients from the OLS and IV regressions are not systematic. For the overidentification test, Ho: E[residuals * instruments] $=0$. White-robust standard errors in brackets. 
Table 7: More Detailed Coding of Capital Account Restrictions

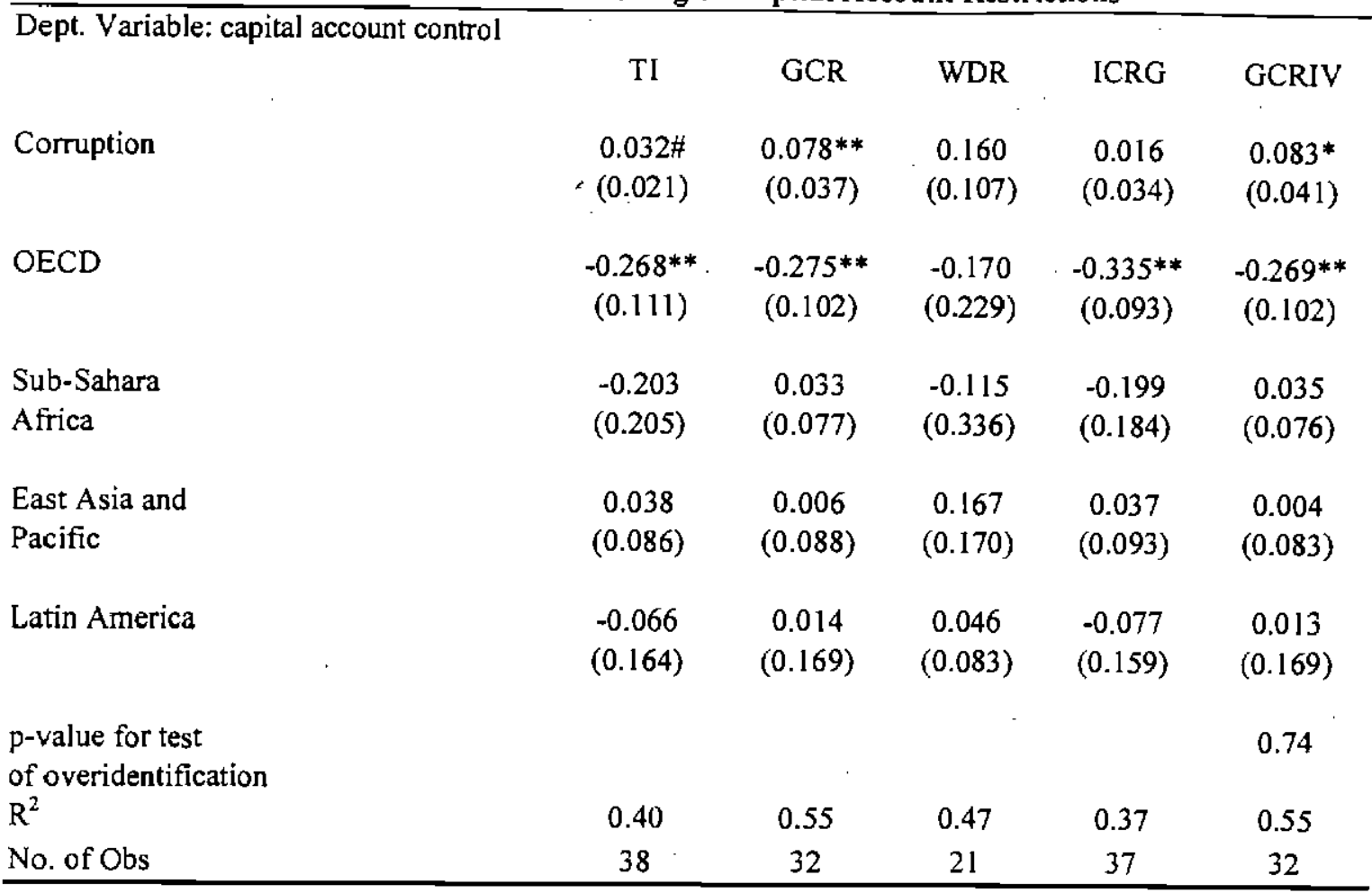

Table 8: Corruption and Tax Evasion

\begin{tabular}{|c|c|c|c|c|c|c|c|c|}
\hline \multicolumn{9}{|c|}{ Dept. Variable: tax evasion } \\
\hline $\begin{array}{l}\text { Measure of } \\
\text { Comuption }\end{array}$ & $\mathrm{T} 1$ & $\mathrm{Tl}$ & GCR & GCR & WDR & WDR & $\begin{array}{c}\text { legal } \\
\text { Corruption }\end{array}$ & $\begin{array}{c}\text { legal } \\
\text { corruption }\end{array}$ \\
\hline Corruption & $\begin{array}{c}0.333^{* *} \\
(0.035)\end{array}$ & $\begin{array}{l}0.374^{* *} \\
(0.046)\end{array}$ & $\begin{array}{l}0.597^{* *} \\
(0.071)\end{array}$ & $\begin{array}{l}0.613^{* *} \\
(0.084)\end{array}$ & $\begin{array}{l}0.834^{* *} \\
(0.182)\end{array}$ & $\begin{array}{l}0.841^{* *} \\
(0.188)\end{array}$ & $\begin{array}{c}0.505^{* *} \\
(0.071)\end{array}$ & $\begin{array}{l}0.497 * * \\
(0.095)\end{array}$ \\
\hline $\begin{array}{l}\text { Statutory tax } \\
\text { Rate }\end{array}$ & $\begin{array}{l}3.313^{*} \\
(1.164)\end{array}$ & $\begin{array}{l}2.719 * * \\
(1.101)\end{array}$ & $\begin{array}{l}3.534^{* *} \\
(0.995)\end{array}$ & $\begin{array}{l}3.397 * * \\
(1.017)\end{array}$ & $\begin{array}{l}4.810^{* *} \\
(1.060)\end{array}$ & $\begin{array}{l}4.776^{* *} \\
(1.211)\end{array}$ & $\begin{array}{l}4.799 * * \\
(1.216)\end{array}$ & $\begin{array}{l}4.852^{* *} \\
(1.154)\end{array}$ \\
\hline OECD & & $\begin{array}{c}0.320 \\
(0.237)\end{array}$ & & $\begin{array}{c}0.080 \\
(0.243)\end{array}$ & & $\begin{array}{c}0.027 \\
(0.318)\end{array}$ & & $\begin{array}{c}-0.041 \\
(0.293)\end{array}$ \\
\hline $\mathrm{R} 2$ & 0.7 & 0.71 & 0.7 & 0.7 & 0.74 & 0.74 & 0.61 & 0.61 \\
\hline No. of Obs & 42 & 42 & 42 & 42 & 23 & 23 & 42 & 42 \\
\hline
\end{tabular}

